\title{
Diversity of the Terrestrial Molluscs of an Urban Secondary Forest: The National Center for Floristry (NCF) of Abidjan, Côte d'Ivoire
}

\author{
N’dri Kouassi Jerome, \\ Amani N'dri Saint Clair, \\ Karamoko Mamadou, \\ Otchoumou Atcho,
} Training and Research Unit of the Sciences of Nature, Nangui Abrogoua University of Abidjan, Côte d'Ivoire

Doi: 10.19044/esj.2019.v15n9p353～URL:http://dx.doi.org/10.19044/esj.2019.v15n9p353

\begin{abstract}
The diversity of terrestrial Molluscs was studied in the National Center for Floristry (NCF) located at the University Felix Houphouet Boigny of Abidjan (Côte d'Ivoire) by combining the direct method and method of sampling litter. A total of 2626 individuals, belonging to 22 species and six families, were harvested from the 15 plots of the study area. Species richness ranges from eight to 21 species with an average of $12.66 \pm 3.73$. It was dominated by Subulinidae (50\%) which are herbivores, and Streptaxidae (22.73\%) which are carnivorous. Each plot yielded between 65 and 392 individuals (mean $175.06 \pm 77.54)$. Numerical abundance was dominated respectively by Archachatina ventricosa with $23.61 \%$ (620 specimens), Limmicolaria flammea with $21.36 \%$ (561 specimens), and Achatina fulica with $16.60 \%$ (436 specimens). Based on the importance of the diversity of Molluscs, steps must be taken towards a better management policy for this center because these species has already been threatened by human activities.
\end{abstract}

Keywords: Diversity, Molluscs, National Center for Floristry, Félix Houphouët Boigny University, Côte d'Ivoire

\section{Introduction}

In recent decades, work on the diversity of terrestrial Molluscs has become numerous. This interest of researchers on these animals is due to the fact that Molluscs play several important roles in forest ecosystems. They are prey for many animals; they are decomposers and therefore participate in mineralization and soil fertilization (Abele et al., 2013). These are bio- 
indicators of the quality of the environment (De Vaufleury et al., 2009). Molluscs are also used in medicine to treat bleeding and various conditions in gynecology (Damerdji, 1990). It is also used to treat anemia, hypertension, pain, constipation (Adikwu, 2012), cough, measles, and tuberculosis (Ademolu et al., 2015). In human nutrition, the flesh of some Molluscs, especially that of giant snails, has been widely consumed since prehistoric times (Murphy, 2001).

Unfortunately, the forest that is the habitat of choice for these animals is the subject of several negative anthropogenic actions. It is destroyed for the establishment of crops and especially for urbanization. Thus, Côte d'Ivoire is an example of the drastic destruction of the forest (MINEF, 2015). This destruction is accompanied by the loss of biodiversity. To preserve this biodiversity, several parks, reserves, and research stations have been created including the National Center for Floristry (NCF). However, the study of the diversity of Molluscs of this center aims not only to widen the knowledge on the diversity of these animals in Côte d'Ivoire, but most especially to highlight the important role that this center plays in the conservation of biodiversity.

\section{Material and Methods Study Environment}

The National Center for Floristry (NCF) is located at the University Felix Houphouet Boigny (UFHB) of Abidjan. It is located between $05^{\circ} 19^{\prime} \mathrm{N}$ and $04^{\circ} 01^{\prime} \mathrm{W}$. It is a traversed internal and peripheral alley delimiting several thematic plots (Kouamé, 2013) (Figure 1). 


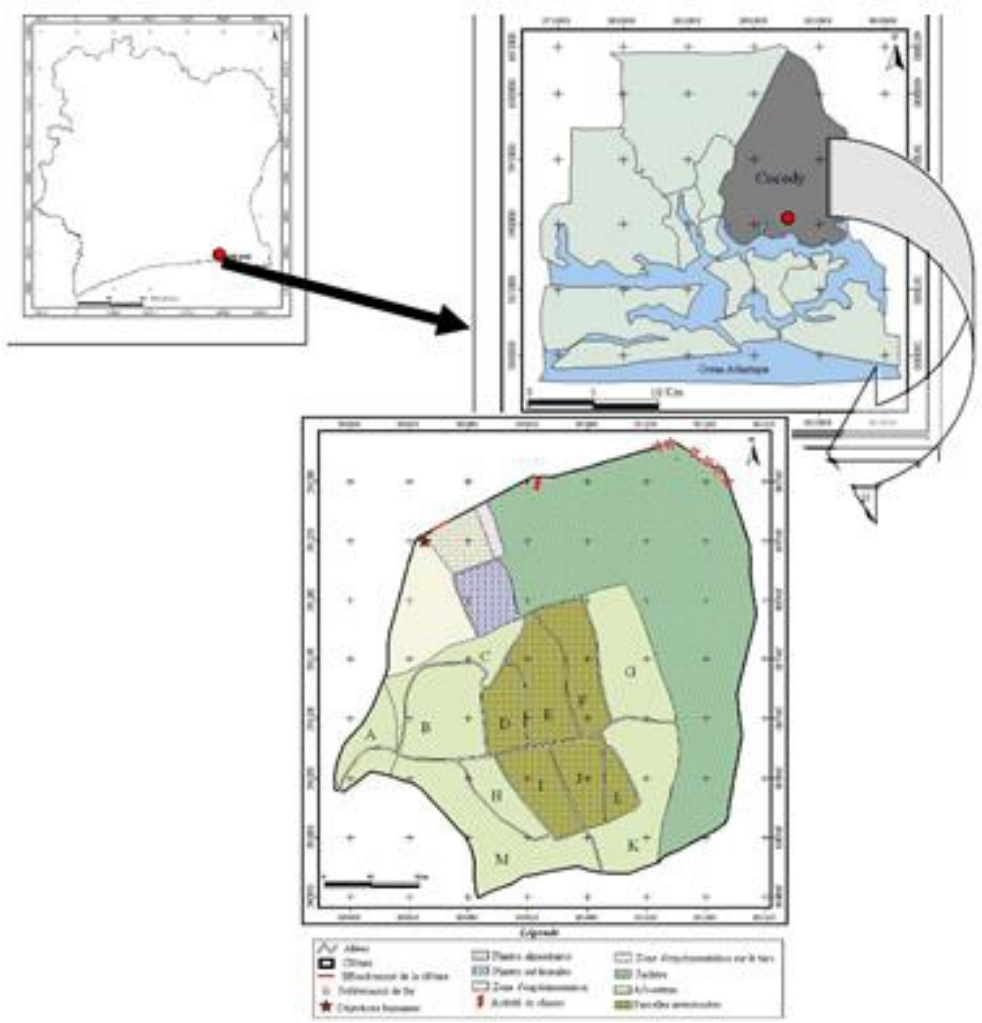

Figure 1. Location of the National Center for Floristry (NCF) within the University Felix Houphouet Boigny (former University of Cocody)

The climate of the NCF in Abidjan is a Guinean type (Doumbia, 2014). Indeed, it is characterized by four seasons differentiated by their rainfall regime: the great rainy season which starts from March to July with a maximum of precipitation in June and the small rainy season which covers the months of October and November with a maximum of precipitation in October. These two wet seasons are separated by a short dry season that runs from August to September and a long dry season that runs from December to February.

The vegetation of the NCF is dominated by dense moist evergreen forest. It is characterized by the presence of two species: Turraeanthus africanus (Welw, Ex.C.C.) Pellegr (Meliaceae) and Heisteria parvifolia of the family Olacaceae (NCF, 1998). NCF is also populated with savanna species and species from other ecological zones that are more discrete. The arboretum of the botanical garden houses is an important collection of plants estimated at 750 species belonging to the Ivorian flora, as well as that of the sub-region (NCF, 1998). In addition, the NCF has a herbarium containing 
about 19,500 samples of species belonging to the Ivorian and West African flora (NCF, 1998).

\section{Sampling Method}

Sampling took place from January 2017 to December 2017 within a period of 12 months. To do so, stratified sampling was retained. It is appropriate when the area of interest is not homogeneous. Therefore, this is often the case in nature because most other methods have the disadvantage of neglecting small areas, but they are original (Adam et al., 2015). This type of sampling is appropriate for the NCF because it is a very heterogeneous forest. This strategy allows both to characterize the study area in its entirety, but also part by part (Cucherat \& Demuynck, 2008). This method provides both lists of species (qualitative sampling) and quantitative data on the abundance of these species, expressed in terms of indices or densities (quantitative sampling) (Adam et al., 2015). The NCF forest has two main parts: an arboretum with an area of 4.25 hectares divided into 11 plots by artificial boundaries and numbered from 1 to 11 (Table 1). Each of these parcels is assigned a name. As for the part not yet exploited, it is a secondary forest still known as a fallow area of 6 hectares. For sampling reasons, we divided this forest into four parts denoted $\mathrm{J} 1, \mathrm{~J} 2, \mathrm{~J} 3$, and $\mathrm{J} 4$. We have delimited quadras on all plots. For all plots to be evenly sampled, the size of a quadras is equal to $2.5 \%$ of the area of the parcel it contains. Each month, a new quadras is randomly delimited on each parcel under the same conditions so that we have had 15 quadras per month. This method allowed us to explore almost the entire area of our plots.

Two survey methods were used for molluscan collection: the so-called direct or sighted survey method for large species and the soil and litter sampling method for micro-species (Oke \& Chokor, 2009). In addition, Emberton et al. (1996) recommend a similar approach by combining timing, direct visual search, soil harvesting, and litter for a quantitative study of Molluscs in forests. The direct method consists of an intensive search of each plot by two active researchers for one hour, between $18 \mathrm{~h}$ and $24 \mathrm{~h}$, or between $24 \mathrm{~h}$ and $6 \mathrm{am}$. All the places likely to shelter snails, in particular the wet places, were prospected.

Table 1. Nomenclature of plots of the NCF

New Appellations

Characteristic Species of Plots

Old

Appellations

01

Anadio de Bénin

Chrysophyllum albidum

$\mathrm{A}+\mathrm{B}$

02

Boborou

Irvingia gabonensis

$\mathrm{C}$ 


\begin{tabular}{llll}
\hline 03 & Tiama & Entandrophragma angolense & $\mathrm{D}$ \\
04 & Niangon & Heritiera utilis & $\mathrm{E}$ \\
05 & Acajou & Khaya spp. & $\mathrm{F}$ \\
06 & Adjouaba & Dacryodes klaineana & $\mathrm{G}$ \\
07 & Okoué & Baphia nitida & $\mathrm{K}$ \\
08 & Obéro & Picralima nitida & $\mathrm{L}$ \\
09 & Makoré & Tieghemella heckelii & $\mathrm{J}$ \\
10 & Fraké & Terminalia superba & $\mathrm{I}$ \\
11 & Palmier & Palmiers & $\mathrm{M}+\mathrm{H}$ \\
12 & Jachère 1 & & $\mathrm{N}+\mathrm{O}+\mathrm{P}$ \\
13 & Jachère 2 & & $\mathrm{Q}$ \\
14 & Jachère 3 & & $\mathrm{R}$ \\
15 & Jachère 4 & $\mathrm{S}$ \\
\hline
\end{tabular}

Thus, snails on the ground, on or under the leaves of shrubs, on the branches and on the trunks of living or dead trees, were collected. During each outing, $5 \mathrm{dm}^{3}$ of soil were collected in each plot as most of the microspecies live in this soil thickness. This soil was dried in a dry and cool place at $18^{\circ} \mathrm{C}$ for four days and was then sieved on a sieve column with decreasing mesh size (10 $\mathrm{mm}$ to $3 \mathrm{~mm}$ ). Each sieve refusal was searched and the part of the soil that passed through the $3 \mathrm{~mm}$ mesh was searched with a magnifying glass. This method is called indirect. Identification of the specimens was done using morphological criteria and with the use of standard identification keys (Daget, 2003; Rowson, 2009; Oke, 2013).

\section{Data Analysis}

The diversity of Molluscs was measured through the overall species richness (S) and the Whittaker index (I), which is the total number of species recorded (S) divided by the average number of species per site $(\alpha)$. This index provides a measure of the difference in diversity between sites (Schilthuizen $\&$ Rutjes, 2001). If I equals 1, the sites have identical faunas and higher values indicate increasing differentiation. True diversity was estimated by 
performing 500 randomizations on the data and calculating $\mathrm{S}$ using the second order Chao 2 and jackknife richness estimators in the PAST 3.0 program.

The Shannon-Weaver $\left(\mathrm{H}^{\prime}\right)$ diversity index, which quantifies the heterogeneity of the environment, was determined for each plot. Thus, the expression is as follows (Shannon, 1948):

$$
\mathrm{H}^{\prime}=-\Sigma \text { pi } \log 2 \mathrm{pi}
$$

With $\mathrm{i}=1$ to $\mathrm{S}$. pi $=\mathrm{ni} / \mathrm{N}$ is the relative frequency of species $\mathrm{i}$, i.e. the probability of occurrence of species $\mathrm{i}$ (ni) over the total number of individuals (N) and $\mathrm{S}$ is the number of species. Also, to know if the different taxa of Molluscs are distributed equally or not inside the parcels, the index of Equitability E (or the regularity E) was determined for each parcel. Equitability $(\mathrm{E})$ is defined as the ratio of calculated diversity to maximum diversity. Thus, the expression is as follows (Shannon, 1948):

$\mathrm{E}=\mathrm{Ish} / \mathrm{Ish} \max$; Ish $\max =\log 2 \mathrm{~S}$ (where $\mathrm{S}$ is the number of species)

In addition, the Sorensen (Is) index was calculated to evaluate the similarity between the different plots. It is calculated according to the following formula:

$$
\text { Is }=(2 \mathrm{C}) /(\mathrm{A}+\mathrm{B})
$$

$\mathrm{C}$ : represents the number of common species between two habitats.

A: represents the number of species for the habitat 1 .

B: represents the number of species for the habitat 2 .

This index varies from 0 when there are no common species between the two habitats, to 1 when all the species found in habitat 1 also exist in the habitat 2.

We used sample-based rarefaction curves to produce a smooth curve that estimates the number of species observed for a smaller number of samples, assuming a random mix of sample order (Gotelli \& Colwell, 2001). Therefore, we defined the intensity of the sample as the ratio of individuals to species (Oke \& Chokor, 2009). The Pearson correlation was used to show the relationship between the number of individuals and the number of species, using the $\mathrm{R}$ software.

\section{Results}

This study identified 2626 individuals divided into 22 species, 14 genera, and six families, namely Achatinidae, Streptaxidae, Subulinidae, Enidae, Ferussaciidae, and Succinidae (Table 2). Each plot yielded between 65 and 392 specimens with an average of $175.06 \pm 77.54$ specimens, and between 8 and 21 specimens with an average of $13.40 \pm 3.28$. The Tiama plot provided the smallest number of species and specimens, eight species and 65 specimens respectively, while the $\mathrm{J} 2$ and $\mathrm{J} 4$ parcels provided the most species (21 species) and the plot Palmiers provided the most specimens (392 specimens). The Shannon index ranged from 1.45 (Palmiers plot) to 2.56 (J2 
plot) with an average of $1.97 \pm 0.27$ reflecting a heterogeneity in the distribution of species. The Fairness index, which varies between 0.55 (Palmiers plot) and 0.90 (Niangon plot) with an average of $0.77 \pm 0.07$, reflects the unequal distribution of species within the NCF. The values of the Sorensen index calculated between the different plots are shown in Table 4. These values are almost all greater than 0.5 . Only the Is between plot Tiama and $\mathrm{J} 2$ is less than 0.5 (Is $=0.48$ ). These results show a great similarity between the species found on the different plots. This index calculated between the arboretum and the fallow gave the value 0.84 . Therefore, the dendrogram of Figure 2 presents the levels of similarity between the different parcels of the NCF. It appears that, except for plot 13 (J1), all the other plots in the fallow are more than $90 \%$ similar, while the similarity between plots of the aboretum varies from $75 \%$ to $95 \%$. The estimate of species richness based on Chao 2 and Jack 2 gave the values 22 and 20.3 species respectively. The Whittaker index of 1.62 indicates a clear difference between the different plots. The relationship between number of species and numerical abundance is presented in Figure 3. Therefore, there is a positive correlation $(r=0.42)$ but low between the number of species per site and the number of individuals harvested on this site. This correlation is not significant $(\mathrm{P}>0.05)$. 


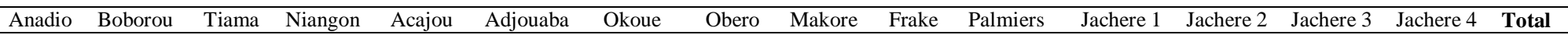

\begin{tabular}{|c|c|c|c|c|c|c|c|c|c|c|c|c|c|c|c|c|}
\hline Achatinidae & & & & & & & & & & & & & & & & 1617 \\
\hline $\begin{array}{l}\text { Archachatina } \\
\text { ventricosa }\end{array}$ & 90 & 27 & 12 & 15 & 48 & 50 & 48 & 18 & 34 & 93 & 119 & 37 & 13 & 8 & 8 & 620 \\
\hline $\begin{array}{l}\text { Achatina fulica } \\
\text { Limmicolaria }\end{array}$ & 52 & 7 & 7 & 15 & 19 & 21 & 49 & 11 & 25 & 110 & 108 & 7 & 0 & 3 & 2 & 436 \\
\hline flammea & 117 & 12 & 31 & 13 & 32 & 51 & 31 & 17 & 46 & 46 & 135 & 15 & 4 & 7 & 4 & 561 \\
\hline Subulinidae & & & & & & & & & & & & & & & & 919 \\
\hline curvella sp 1 & 10 & 4 & 4 & 4 & 3 & 0 & 10 & 2 & 5 & 10 & 2 & 4 & 32 & 36 & 38 & 164 \\
\hline Curvella sp 2 & 0 & 0 & 0 & 0 & 0 & 0 & 0 & 0 & 0 & 0 & 0 & 0 & 2 & 3 & 2 & 7 \\
\hline Curvella sp 3 & 8 & 8 & 0 & 0 & 3 & 8 & 0 & 2 & 3 & 8 & 4 & 5 & 11 & 8 & 4 & 72 \\
\hline Curvella sp 4 & 0 & 0 & 0 & 0 & 0 & 0 & 0 & 0 & 0 & 0 & 0 & 0 & 5 & 3 & 1 & 9 \\
\hline curvella sp 5 & 0 & 0 & 0 & 0 & 1 & 5 & 3 & 0 & 3 & 0 & 0 & 6 & 10 & 7 & 6 & 41 \\
\hline Pseudopea sp 1 & 4 & 3 & 3 & 4 & 0 & 6 & 6 & 0 & 5 & 8 & 0 & 6 & 29 & 27 & 31 & 132 \\
\hline subulina sp 1 & 3 & 0 & 0 & 3 & 2 & 0 & 4 & 5 & 3 & 9 & 2 & 3 & 5 & 12 & 19 & 70 \\
\hline Subulona martensi & 3 & 1 & 1 & 0 & 0 & 2 & 1 & 3 & 3 & 3 & 5 & 4 & 6 & 9 & 4 & 45 \\
\hline $\begin{array}{l}\text { opeas sp } 1 \\
\text { striosubilina }\end{array}$ & 6 & 3 & 0 & 3 & 1 & 6 & 0 & 0 & 4 & 4 & 5 & 8 & 6 & 5 & 3 & 54 \\
\hline $\begin{array}{l}\text { striatella } \\
\text { curvella }\end{array}$ & 10 & 6 & 3 & 4 & 5 & 8 & 4 & 4 & 4 & 9 & 2 & 9 & 21 & 26 & 15 & 130 \\
\hline subvirescens & 16 & 9 & 4 & 7 & 6 & 10 & 7 & 4 & 4 & 13 & 4 & 7 & 39 & 23 & 42 & 195 \\
\hline Streptaxidae & & & & & & & & & & & & & & & & 73 \\
\hline $\begin{array}{l}\text { Ennea elegantula } \\
\text { (Pfeiffer, 1848) }\end{array}$ & 0 & 0 & 0 & 0 & 0 & 0 & 0 & 0 & 0 & 0 & 1 & 0 & 6 & 1 & 6 & 14 \\
\hline Gullela io & 2 & 1 & 0 & 0 & 0 & 0 & 0 & 2 & 0 & 3 & 1 & 3 & 3 & 1 & 10 & 26 \\
\hline Gullela sp 1 & 0 & 0 & 0 & 0 & 1 & 0 & 0 & 0 & 0 & 1 & 2 & 3 & 1 & 3 & 4 & 15 \\
\hline Gonaxis sp 1 & 0 & 0 & 0 & 0 & 0 & 0 & 0 & 0 & 0 & 0 & 0 & 3 & 3 & 2 & 1 & 9 \\
\hline Gullela sp 2 & 0 & 0 & 0 & 0 & 0 & 0 & 0 & 0 & 0 & 0 & 0 & 0 & 5 & 2 & 2 & 9 \\
\hline Enidae & & & & & & & & & & & & & & & & 4 \\
\hline $\begin{array}{l}\text { Rachinida } \\
\text { tumefacta } \quad \text { (Reeve, } \\
\text { 1849) }\end{array}$ & 0 & 0 & 0 & 0 & 0 & 0 & 0 & 0 & 0 & 0 & 0 & 0 & 3 & 0 & 1 & 4 \\
\hline Ferussaciidae & & & & & & & & & & & & & & & & 3 \\
\hline Cecilioides $s p$ & 0 & 0 & 0 & 0 & 0 & 0 & 0 & 0 & 0 & 0 & 0 & 0 & 2 & 0 & 1 & 3 \\
\hline Scuccineidae & & & & & & & & & & & & & & & & 10 \\
\hline
\end{tabular}




\begin{tabular}{|c|c|c|c|c|c|c|c|c|c|c|c|c|c|c|c|c|}
\hline Quickia concise & 1 & 0 & 0 & 0 & 0 & 1 & 1 & 0 & 0 & 1 & 2 & 0 & 1 & 3 & 0 & 10 \\
\hline TOTAL & 322 & 81 & 65 & 68 & 121 & 168 & 164 & 68 & 139 & 318 & 392 & 120 & 207 & 189 & 204 & 2626 \\
\hline
\end{tabular}

Table 2. List of Molluscs collected in the NCF forest

\begin{tabular}{|c|c|c|c|c|c|c|c|c|c|c|c|c|c|c|c|}
\hline & ANADIO & BOBOROU & TIAMA & NIANGON & ACAJOU & ADJOUABA & OKOUE & OBERO & MAKORE & FRAKE & PALMIERS & $\mathrm{J} 1$ & $\mathrm{~J} 2$ & $\mathrm{~J} 3$ & $\mathrm{~J} 4$ \\
\hline ANADIO & 1 & & & & & & & & & & & & & & \\
\hline BOBOROU & 0,92 & 1 & & & & & & & & & & & & & \\
\hline TIAMA & 0,76 & 0,84 & 1 & & & & & & & & & & & & \\
\hline NIANGON & 0,82 & 0,8 & 0,82 & 1 & & & & & & & & & & & \\
\hline ACAJOU & 0,75 & 0,73 & 0,63 & 0,8 & 1 & & & & & & & & & & \\
\hline ADJOUABA & 0,83 & 0,82 & 0,74 & 0,7 & 0,73 & 1 & & & & & & & & & \\
\hline OKOUE & 0,83 & 0,73 & 0,84 & 0,8 & 0,73 & 0,82 & 1 & & & & & & & & \\
\hline OBERO & 0,87 & 0,86 & 0,78 & 0,74 & 0,76 & 0,67 & 0,76 & 1 & & & & & & & \\
\hline MAKORE & 0,88 & 0,87 & 0,8 & 0,86 & 0,87 & 0,87 & 0,87 & 0,82 & 1 & & & & & & \\
\hline FRAKE & 0.96 & 0,88 & 0,73 & 0,78 & 0,8 & 0,8 & 0,8 & 0,83 & 0,85 & 1 & & & & & \\
\hline PALMIERS & 0,89 & 0,8 & 0,64 & 0,69 & 0,8 & 0,72 & 0,72 & 0,83 & 0,77 & 0,93 & 1 & & & & \\
\hline $\mathrm{J} 1$ & 0,86 & 0,85 & 0,69 & 0,75 & 0,85 & 0,77 & 0,77 & 0,8 & 0,89 & 0,90 & 0,83 & 1 & & & \\
\hline $\mathrm{J} 2$ & 0,70 & 0,62 & 0,48 & 0,53 & 0,62 & 0,62 & 0,62 & 0,58 & 0,67 & 0,73 & 0,74 & 0,78 & 1 & & \\
\hline $\mathrm{J} 3$ & 0,79 & 0,71 & 0,57 & 0,62 & 0,71 & 0,71 & 0,71 & 0,67 & 0,75 & 0,82 & 0,82 & 0,86 & 0,92 & 1 & \\
\hline J4 & 0,70 & 0,69 & 0,55 & 0.6 & 0,69 & 0,62 & 0,62 & 0,64 & 0,73 & 0,74 & 0,74 & 0,83 & 0,95 & 0,97 & 1 \\
\hline
\end{tabular}

Table 3. Values of the Sorensen index between the lots of the NCF 


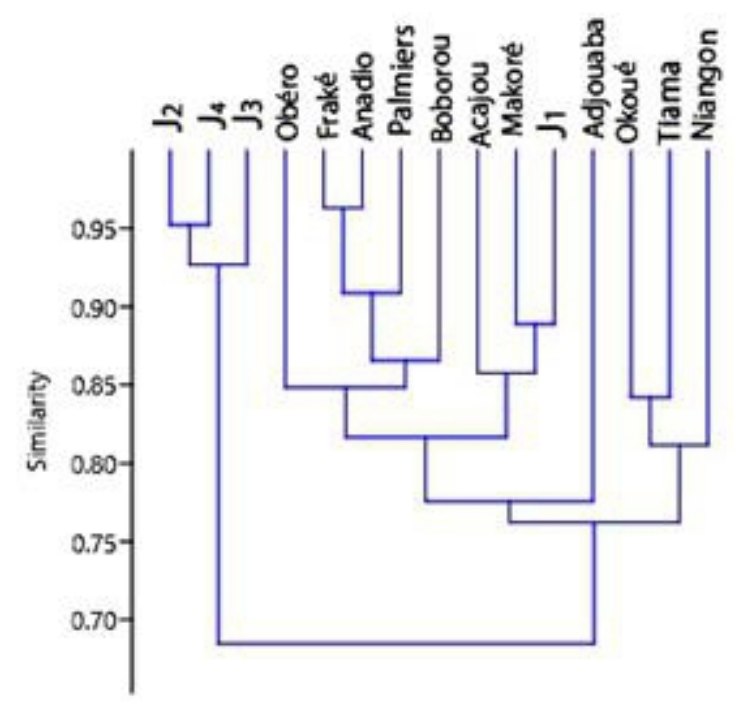

Figure 2. Dendrogram of regrouping plots of the NCF according to their similarity

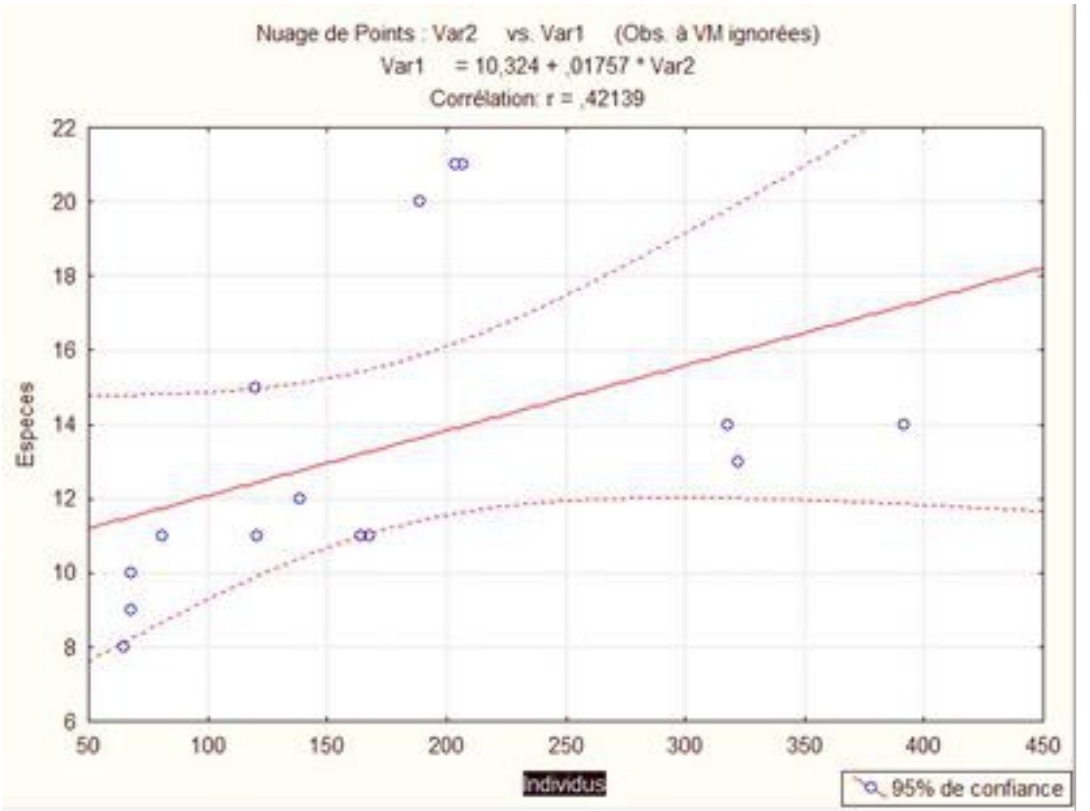

Figure 3. Relationship between the number of species and the number of individuals harvested in the NCF forest

Species richness is dominated by two families, the Subulinidae family with six genera and 11 species, or $50 \%$ of all species, and the family Streptaxidae with three genera and five species accounting for $22.73 \%$ of the 
species recorded. The Achatinidae family has an intermediate species richness because it comprises of three genera and three species, i.e. 13.63\%. Three families (Enidae, Ferussaciidae and Succineidae) are each represented by one genus and one species, i.e. 5.54\% for each of these families.

With regard to abundance, the family Achatinidae is the most represented with 1617 specimens or $61.57 \%$ of the specimens. The Subulinidae family followed respectively with 724 individuals or $27.57 \%$, the Streptaxidae family with 73 specimens or $2.77 \%$ of the specimens, the Succineidae family with 10 specimens representing $0.38 \%$, the Enidae family with 4 individuals or $0.15 \%$, and finally the family Ferussaciidae with 3 specimens or $0.11 \%$ of the specimens.

Three species (Archachatina ventricosa, Limmicolaria flammea and Achatina fulica) are very abundant with 620, 561, and 436 individuals respectively. Seven have intermediate abundance (numbers between 50 and 200 individuals) while 12 species are rare (less than 50 individuals) (Figure 4). Archachatina ventricosa is the most abundant species with $23.61 \%$ (620 specimens). This was followed respectively by Limmicolaria flammea with $21.36 \%$ (561 specimens), Achatina fulica with $16.60 \%$ (436 specimens), curvella subvirescens with $7.42 \%$ (195 specimens), and curvella sp 1 with $6.24 \%$ (164 specimens). The species Cecilioides sp species is the least abundant with only $0.11 \%$ ( 3 specimens). The rarefaction curve increases to the eleventh sample before stabilizing and reaching the asymptote (Figure 5).

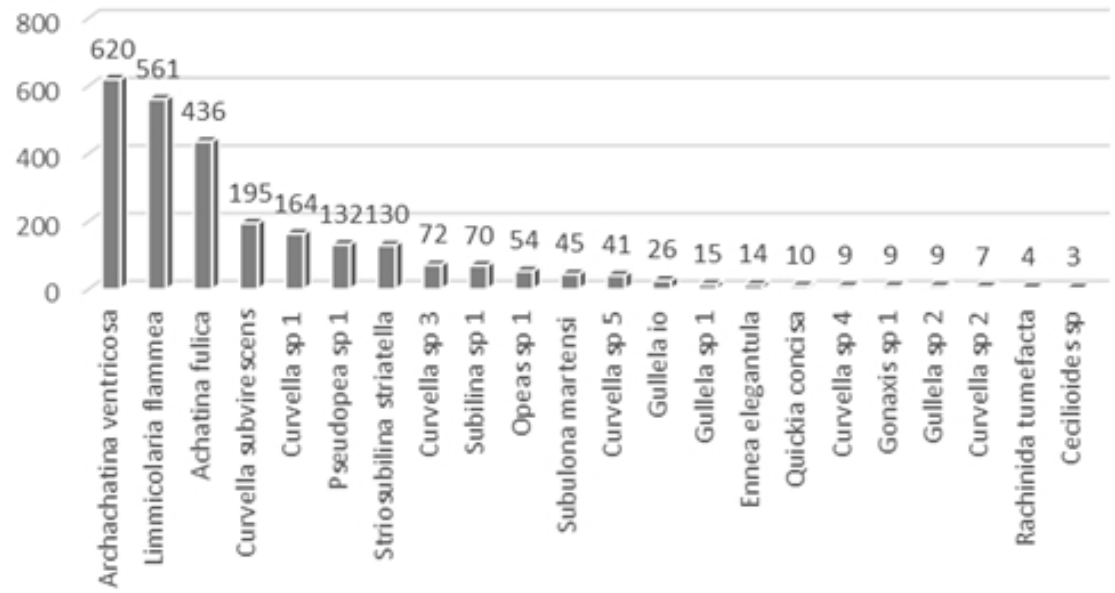

Figure 4. NCF's Plural Abundance Plot of the Terrestrial Molluscs 


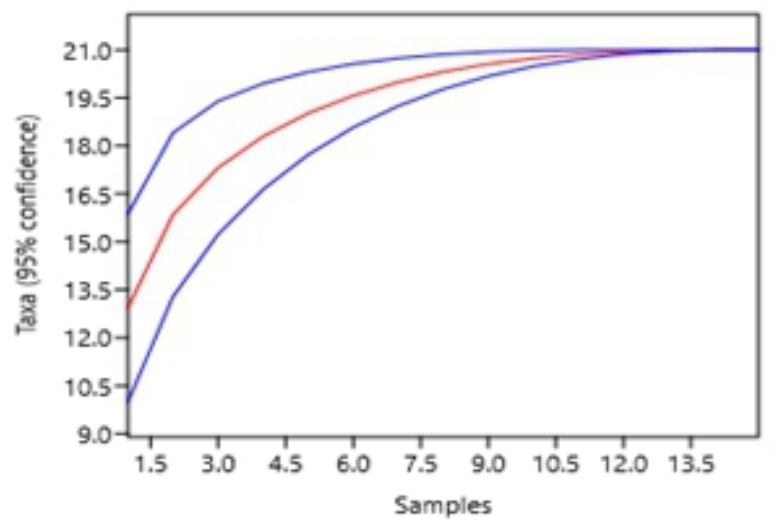

Figure 5. Curve of rarefaction of the species according to the sampling of the NCF's terrestrial Molluscs

\section{Discussion}

This study on the diversity of terrestrial Gastropod Molluscs at the Abidjan National Center of Floristry (NCF) has collected 22 species divided into six families. This number of species is small compared to that harvested by Wronski and Hausdorf (2009) (169 species) in Uganda, by Fontaine et al. (2007) (74 species) in Gabon, by Schuilthuizen and Rutjes (2001) (61 species) in one square kilometer Rainforest Sabah Rainforest in Borneo, Malaysia, by Oke and Chokor (2009) (60 species) in the rainforest in southwestern Nigeria, by Daget (2003) (45 species) in the Mont Nimba Forest in Côte Ivory, and by Amani et al. (2016) (28 species) in the Yapo classified forest in Côte d'Ivoire. This low number of species in our work can be explained by the fact that the works cited above took place in primary forest, while the NCF, our study area, is an urban secondary forest planted at more than 50\%. Therefore, the result of some characteristic species of these primary forests, such as Achatina achatina and slugs, were absent. Who could explain this weakness in the area of the NCF which is only ten hectares? This area is very small compared to the forest areas mentioned above. In addition, the soil $\mathrm{pH}$ of the NCF between 4.7 and 5.8 with an average of $5.1 \pm 0.24$ can justify this weakness of the species richness. Indeed, Tattersfield et al. (2001) observed that species richness is low when the soil is more or less acidic. In addition, the average study area altitude of around $65 \mathrm{~m}$ can help to justify this weakness in species richness. Wronski et al. (2014) and Tattersfield et al. (2001) showed that the species richness is maximum between $400 \mathrm{~m}$ and $600 \mathrm{~m}$ altitude. Nevertheless, the number of species harvested is greater than that recorded by 
Damerdji (2014) (16 species) on two Lamiaceae species in northwestern Algeria, by Larbaa and Soltani (2013) (14 species) in northeastern Algeria, by Memel et al. (2008) (8 species) in the Banco National Park in Côte d'Ivoire, and by Dayasiri et al. (2014) (2 terrestrial species) in southern Sri Lanka. The species richness is dominated by the family Subulinidae (herbivores) followed by the family of Streptaxidae (carnivores). These results are in agreement with those of Amani (2016) and Wronski et al. (2014). Consequently, there is a great similarity between the species harvested on the different parcels of the NCF. This can be explained by the small size of the said center. Indeed, the area of the center being only 10 ha, abiotic parameters such as temperature and relative humidity, vary very little from one plot to another. However, the fallow plots $\mathrm{J} 2, \mathrm{~J} 3$, and $\mathrm{J} 4$ are clearly different from the plot J1. The latter was originally intended for the experimentation of certain crops such as banana, taro, and cassava. As a result, it is not an original forest like the others. This resulted in a dominance of Achatinidae on this plot compared to other plots of fallow.

In terms of numerical abundance, it is dominated by the three species of the Achatinidae family: Archachatina ventricosa with 620 individuals or $23.61 \%$, Limmicolaria flammea with 561 individuals or $21.36 \%$, and Achatina fulica with 436 individuals or $16.60 \%$ of all species. The abundance of these species can be explained firstly by the fact that the NCF in general and the arboretum in particular offers them the conditions of their blossoming and their proliferation. Indeed, the arboretum with more than 750 plant species offers a varied range of nutritious plants to Achatinidae. Thus, these species feed on wild plants (Otchoumou et al., 2003), but are highly prized on cultivated plants (Otchoumou et al., 1989-1990).

The many human activities that take place in the arboretum (educational activities and research, sightseeing, and regular cleaning) seem not to disturb these animals. Moreover, Karamoko in 2009 noted that these animals adapt to the human presence and even feed on the remains of food rejected by humans. In addition, there are reservoirs of water on three parcels of the arboretum. These reservoirs drain the arboretum so that even during the dry season, it remains relatively wet. This favors a grouping of these species in the arboretum during this season. Achatinidae, like most terrestrial Molluscs, are found in moist areas (Otchoumou et al., 1989-1990). Then, in terms of food, Archachatina ventricosa, Limmicolaria flammea, and Achatina fulica are not subject to a collection pressure like other Achatinidae such as Achatina achatina. Ivorian populations generally consume little or no quantity of Limmicolaria flammea and Achatina fulica. According to Kouassi (2008), Achatina achatina is the most consumed species among Achatinidae by Ivorian forest populations. The species Archachatina ventricosa and Achatina fulica are less appreciated and are consumed by default. 
Basically, there are only three (3) abundant species. On the other hand, intermediate abundance species and rare species are the most abundant. These results indicate that the biodiversity of NCF's terrestrial Molluscs is highly threatened. It will therefore be necessary to pay special attention to these animals. In addition, the species accumulation curve that grows to the tenth sample before reaching the asymptote shows that sampling was maximum. The value of the Whittaker index (1.62) obtained is relatively small. This result reflects a great similarity between the harvested species. In fact, apart from fallow plots, almost all species are found on all the plots of the arboretum. Curvella sp 2, Gullela sp2, Cecliodes sp and Rachinida tumefacta are only found in fallow, hence the importance of preserving this fallow.

There is a positive $(r=0.42)$ but not significant $(p>0.05)$ correlation between the number of species and the number of individuals per site. This marks a contradiction with the work of Amani (2016), Oke (2013), and Oke and Chokor (2009). These authors observed a significant correlation between the number of species and numerical abundance. Hence, the weakness of the correlation in our work could be due to the fact that in the NCF, the number of species does not necessarily evolve with the number of individuals. It would evolve according to factors such as the availability of food resources and the level of adaptation of species to the many human activities of this center. Thus, it is a loss of biodiversity for the benefit of a few species.

\section{Conclusion}

Work undertaken to evaluate Mollusc biodiversity at the National Center of Floristry (NCF) has revealed the presence of several species of Molluscs at the center. It appears that while some species thrive due to favorable conditions, most micro-species are threatened by human activities. With the discovery of all these species of Molluscs within it, the role of conservation of biodiversity center was amplified. This is why all the provisions must be taken for the sustainability and better management policy of this center.

\section{References:}

1. Abele, S.E., Macdonald, S.E. \& Spence, J.R. (2013). Cover type, environmental characteristics, and conservation of terrestrial gastropod diversity in boreal mixedwood forests. NRC research Press Can. J. For. Res. 44: 36-44 (2014).

2. Adam, Y., Béranger, C., Delzons, O., Frochot, B., Gourvil, J., Lecomte, P., \& Parisot-Laprun, M. (2015). Guide des méthodes de diagnostic écologique des milieux naturels - Application aux sites de carrière. $P$ 49-50. 
3. Ademolu, KO., Akintola, MY., Olalonye, AO. \& Adelabu, BA. (2015). Traditional utilization and biochemical composition of six mollusc shells in Nigeria.

4. Adikwu, M. U. (2012). Snail production for sustainable development and good health. In S. I. Ola, G. A. Dedeke, \& A. O. Fafiolu (Eds.), Procceedings of the 1st International Conference on Giant African Land snails (NeTGALS) (pp. 3-7). Federal University of Agriculture, Abeokuta, Nigeria.

5. Amani, N. S.C., Karamoko, M., Memel, J. D., Otchoumou, A., \& Oke, C.O. (2016). Species richness and diversity of terrestrial molluscs (Mollusca, Gastropoda) in Yapo classified forest, Côted'Ivoire. Journal of Biodiversity and Environmental Sciences (JBES). Vol. 9, No. 1, p. 133-141, 2016

6. CNF (1998). le CNF, un patrimoine national, voire mondial à sauvegarder. CNF, Université de Cocody - Abidjan (Côte d'Ivoire), $15 \mathrm{P}$.

7. Cucherat, X. \& Demuynck, S. (2008). Les plans d'échantillonnage et les techniques de prélèvements des mollusques continentaux. MalaCo, 5: 244-253. Publié sur www.journal-malaco.fr.

8. Daget, J. (2003). Les Mollusques terrestres et fluviatiles du mont Nimba, in LAMOTTE M. \& ROY R. (eds), Le peuplement animal du mont Nimba (Guinée, Côte d'Ivoire, Liberia). Mémoires du Muséum national d'Histoire naturelle 190 : 183-209. Paris ISBN : 2-85653554-2 Dahomey. In $4^{\grave{e ̀ m e}}$ congrès ASS. Int. Sci. Sol (Amsterdam), 1950, PP 127-128

9. Damerdji, A. (2014). Diversité de la malacofaune sur deux espèces de lamiacées (lavandula multifida 1 . Et l. Dentata 1.) Dans la région de Tlemcen (nord- ouest algérien).

10. Damerdji, A. (1990). Contribution à l'Etude Biosystématique des Mollusques Gastéropodes Pulmonés Terrestres de la Région de Tlemcen. Thèse de Magister en Biologie. Institut national d'enseignement supérieur de biologie.

11. Dayasiri, P., Chandana, E.P.S., \& Amarasinghe, N.J.D.S. (2014). A note on snail diversity in selected areas of 'Kirala Kele' eco-touring in southern Sri Lanka. International Journal of Science, Environment and Technology 3(1), 1-9.

12. De Vaufleury, A., Fritsch, C., Gimbert, F., Pauget, B., Coeurdassier, M., Crini, N. \& Scheifler, R. (2009). Utilisation et intérêts des escargots et des micromammifères pour la bioindication de la qualité des sols. Etude et Gestion des Sols, 16, 3/4, 2009 pp 203 - 2018

13. Doumbia, M. (2014). Diversité caractéristique, Biomorphologie des espèces à statut particulier de l'arboretum du Centre National de 
Floristique de l'Université Félix Houphouet Boigny. Mémoire de DEA de Biologie Végétale (Option Ecologie Végétale), U.F.R. Biosciences, Université Félix Houphouet Boigny, Abidjan, Côte d'Ivoire, 47 P.

14. Emberton, K.C., Pierce, T.A., Kasigwa, P.F., Tattersfield, P., \& Habibu, Z. (1997). High diversity and regional endemismin land snails of easternTanzania. Biodiversiiyand Conservation6, 1123-1136.

15. Fontaine, B., Gargominy, O., \& Neubert, E. (2007). Snail diversity of the savanna/forest mosaic in Lope National Park, Gabon. Malacologia 49(2), 313-338.

16. Gotelli, N. \& Colwell, R.K. (2001). Quantifying biodiversity: Procedures and pitfalls in the measurement and comparison of species richness. Ecology Letters4, 379-391.

17. Karamoko, M. (2009). Étude de la biologie, de l'écologie et du comportement d'un escargot terrestre d'intérêt économique, Limicolaria flammea (Müller, 1774), en milieu d'élevage. These de doctorat s écologie animale de l'Université d'Abidjan-Cocody.

18. Kouamé, A.P.S (2013). Diversité Végétale Et Estimation De La Biomasse Dans L'arboretum Du Centre National De Floristique (Abidjan, Côte D'ivoire). Mémoire de DEA D'ÉCOLOGIE TROPICALE Université Félix Houphouet Boigny 78p

19. Kouassi, K. D. (2008). Effet de l'alimentation et du substrat d'élevage sur les performances biologiques de Archachatina ventricosa et quelques aspects de la collecte des escargots géants de Côte d'Ivoire. Thèse de doctorat de 3e cycle, Université d'Abobo-Adjamé (Côte d'Ivoire), $130 \mathrm{p}$.

20. Larba, R. \& Soltani, N. (2013). Diversity of the terrestrial gasteropods in the Nordeast Algeria: Spatial and temporal distribustion. European Journal of Expérimental Biology, 2013, 3(4):209-215.

21. Memel, J.D., Otchoumou, A., Kouassi, D.K. \& Dosso, H. (2008). Inventaire, potentiel et répartition des escargots terrestres d'une forêt tropicale humide de Côte d'Ivoire : le Parc National du Banco (PNB). NOVAPEX, 9 (2-3): 119-127.

22. MINEF (ministère des eaux et forêts, Côte d'Ivoire) (2015). Gestion durable des ressources forestières, Rapport pour les Etats généraux de la forêt, de la faune et des ressources en eau, 89p.

23. Murphy, B. (2001). Breeding and growing snails commercially in Australia. A report of the rural Industries. Research and developpement Corporation publication. $\mathrm{N}^{\circ} 00 / 188$ Project $\mathrm{N}^{\circ} \mathrm{ARH}-$ $1 \mathrm{~A}$.

24. Oke, C.O. \& Chokor, J.U. (2009). The effect of land use on snail species richness and diversity in the tropical rainforest of southwestern Nigeria. African Scientist 10(2), 95-108. 
25. Oke, O. C. (2013). Terrestrial mollusc species richness and diversityin Omo Forest Reserve, Ogun State, Nigeria. African Invertebrates 54(1), 93-104.

26. Otchoumou, A., Dosso, H. \& Fantodji, A. (2003). The edible African Giant Snails: fertility of Achatina achatina (Linné, 1758), Achatina fulica (Bowdich, 1720) and Archachatina ventricosa (Gould, 1850) in humid forest; influence of animal density and photoperiod on the fertility in breeding. Bolletino malacologico, 39: 179-184.

27. Otchoumou, A., Zongo, D. \& Dosso, H. (1989-1990). Contribution à l'étude de l'escargot géant africain Achatina achatina (Linné). Annales d'écologie.

28. Rowson, B. (2009). Systématics and diversity of Streptaxidae (Gastropoda : Stylomatophora). PhD Thesis, Cardiff University, UK, 4-62.

29. Shannon, W. (1948). A mathematical theory of communication. Bell System Technical Journal, 27: 379-423.

30. Schilthuizen, M. \& Rutjes, H.A. (2001). Land snail diversity in a square kilometre of tropical rainforest in Sabah, Malaysian Borneo. Journal of Molluscan Studies 67, 417-423.

31. Tattersfield, P., Warui, C.M., Seddon, M.B. \& Kiringe, J.W. (2001). Land-snail faunas of afromontane forests of Mount Kenya, Kenya: ecology, diversity and distribution patterns, Journal of Biogeography, 28, 843-861.

32. Wronski, T. \& Hausdorf, B. (2009). Diversity and body-size patterns of land snails in rain forests in Uganda. Journal of Molluscan Studies, 76: 87-100.

33. Wronski, T., Gilbert, K., Long, E., Micha, B., Quinn, R., \& Hausdorf, B. (2014). Species richness and meta-community structure of land snails along an altitudinal gradient on Bioko island, Equatorial Guinea. Journal of Molluscan Studies 80, 161-168 XXI : 31-58. 